\title{
Can Imazapic Increase Native Species Abundance in Cheatgrass (Bromus tectorum) Invaded Native Plant Communities?
}

\author{
Adrien C. Elseroad ${ }^{1}$ and Nathan T. Rudd ${ }^{2}$ \\ Authors are ${ }^{1}$ Plant Ecologist and ${ }^{2}$ Biometrician, The Nature Conservancy, Portland, OR 97214, USA.
}

\begin{abstract}
Native plant communities invaded by cheatgrass (Bromus tectorum L.) are at risk of unnatural high intensity fires and conversion to cheatgrass monocultures. Management strategies that reduce cheatgrass abundance may potentially allow native species to expand and minimize further cheatgrass invasion. We tested whether the selective herbicide imazapic is effective in reducing cheatgrass and "releasing" native species in a semiarid grassland and shrub steppe in north-central Oregon. The

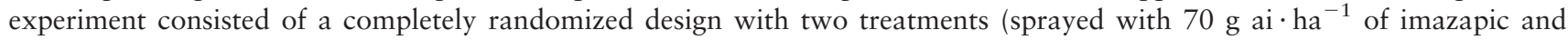
unsprayed) and three replicates of each treatment applied to either 2.5 or 4 ha plots. We repeated this experiment in three different sites dominated by the following native species: 1) bluebunch wheatgrass (Psendoroegneria spicata [Pursh] A. Löve ssp. spicata) and needle and thread (Hesperostipa comata [Trin. \& Rupr.] Barkworth), 2) needle and thread and Sandberg bluegrass (Poa secunda J. Presl), and 3) big sagebrush (Artemisia tridentata Nutt.). Nested frequency of all plant species in 1-m ${ }^{2}$ quadrats was collected for $1 \mathrm{yr}$ pretreatment and $4 \mathrm{yr}$ posttreatment. In all three sites, cheatgrass frequencies were significantly lower in sprayed plots than unsprayed plots for 3-4 yr posttreatment $(P<0.1)$. Other annual plant species were also impacted by imazapic, but the effects were highly variable by species and site. Only two native perennial species, hoary tansyaster (Machaeranthera canescens [Pursh] Gray) and big sagebrush, increased in sprayed plots, and increases occurred only at two sites. These results suggest that a short-term reduction in cheatgrass alone is not an effective strategy for increasing the abundance of most native perennial plant species.
\end{abstract}

\section{Resumen}

Las comunidades de plantas nativas que están invadidas del pasto cheatgrass (Bromus tectorum L.) están en riesgo de fuego intencionales de alta intensidad y convertirse en monocultivos de éste pasto. Estrategias de manejo que reduzcan la abundancia del pasto cheatgrass podrían tener el potencial de permitir que especies nativas se expandan y minimicen la posible invasión por el cheatgrass. Probamos sí el herbicida Imazapicis que es efectivo en reducir el pasto cheatgrass y "liberar" especies nativas en pastizales semiáridos y matorral estepario en la parte centro-norte de Oregon. El experimento consistió en un diseño completamente al azar con dos tratamientos (asperjar con $70 \mathrm{~g}$ ia $\cdot \mathrm{ha}^{-1}$ de Imazapic y sin asperjar) y tres repeticiones por cada tratamiento aplicado ya sea a parcelas de 2.5 o 4 ha. Repetimos el experimento en tres diferentes sitios dominados por las siguientes especies nativas: 1) (Pseudoroegneria spicata [Pursh] A. Löve ssp. spicata) y (Hesperostipa comata [Trin. \&Rupr.] Barkworth), 2) (Hesperostipa comata [Trin. \&Rupr.] Barkworth) y (Poa secunda J. Presl), y 3) Artemisa (Artemisia tridentata Nutt.). Se recolectaron todas las especies en un cuadrante de $1 \mathrm{~m}^{2}$ en frecuencia anidada por un año como pre-tratamiento y cuatro años como post-tratamiento. En todos los sitios las frecuencias de pasto cheatgrass fueron significativamente más bajas en las parcelas asperjadas que en las parcelas de control en tres de cuatro años de post-tratamiento $(P<0.1)$. Otras especies anuales fueron impactadas por Imazapic pero los efectos fueron muy variables por especie y sitio. Solo dos especies perennes nativas (Machaeranthera canescens[Pursh] Gray) y la Artemisa aumentaron en solo dos de las parcelas asperjadas. Estos resultados sugieren que en el corto plazo la reducción de pasto cheatgrass por sí solo no es una estrategia efectiva para aumentar la abundancia de muchas especies de plantas nativas.

Key Words: annual grass invasion, herbicide control, invasive plants, restoration

\section{INTRODUCTION}

Cheatgrass (Bromus tectorum L.) is an introduced annual grass from Eurasia that dominates large portions of the shrubsteppe ecosystems in the Columbia Basin, Great Basin, and Snake River Plains in the western United States (Mack 1981; Whisenant 1990; Knapp 1996; Knick 1999; Menakis et al. 2003). Cheatgrass displaces native perennial plant species by initiating growth in the fall and winter while native plants are

\footnotetext{
Research was funded in part by the BASF Corporation.

Correspondence: Adrien C. Elseroad, Confederated Tribes of the Umatilla Indian Reservation, 46411 Timíne Way, Pendleton, OR, 97801, USA. Email: adrienelseroad@ctuir.org

Manuscript received 20 October 2010; manuscript accepted 27 July 2011.
}

dormant (Harris 1967; Knapp 1996), reducing available soil moisture (Harris 1967; Melgoza et al. 1990; Aguirre and Johnson 1991), and producing large quantities of seed that germinate at very high rates (Hull et al. 1974; Knapp 1996). Cheatgrass also alters other aspects of ecosystem structure, process, and function including nutrient cycling and soil organic matter composition and distribution (Knapp 1996; Norton et al. 2004), but its greatest impacts probably result from its effect on natural fire regimes. At high density, its fine structure and tendency to dry out in early summer creates a highly flammable, continuous fuel source that increases fire frequency, intensity, severity, and extent and promotes further cheatgrass invasion (Stewart and Hull 1949; Young and Evans 1978; Peters and Bunting 1994; Knick 1999). After a series of 
high severity fires fueled by cheatgrass, diverse native plant communities can be converted to a virtual monoculture of cheatgrass and other invasive species (Pellant 1990; Peters and Bunting 1994).

Attempts to restore areas infested with cheatgrass typically consist of one or more site preparation techniques, such as mechanical cultivation, burning, grazing, or herbicides, followed by reseeding with perennial plant species (Pellant 1996; Mosely et al. 1999; Cox and Anderson 2004; Monsen et al. 2004). However, because these techniques are likely to also negatively impact native plant species, they are appropriate only when there are few desirable remnant native plants. Management strategies are needed for invaded sites still supporting a substantial proportion of the native plant community. Methods that temporarily reduce cheatgrass with minimal impacts to native species may provide a window for their recovery without requiring reseeding. An increase in native plant abundance may foster plant community resistance to further weed invasion (Blumenthal et al. 2003; Bakker and Wilson 2004; Biondini 2007).

One method promoted in recent years for controlling cheatgrass and increasing native species is the use of the herbicide imazapic (Plateau ${ }^{\circledR}$ BASF). Several studies in western rangelands have found that imazapic substantially reduces cheatgrass and other invasive annual grasses (Shinn and Thill 2002, 2004; Monaco et al. 2005; Davison and Smith 2007; Kyser et al. 2007; Sheley et al. 2007; Morris et al. 2009; Davies 2010). A main advantage of imazapic over other control methods is that application as a preemergent selectively targets annual species and suppresses germination for several years (Davison and Smith 2007; BASF, personal communication). Although several studies have examined imazapic effects on the establishment of seeded species (Beran et al. 1999; Shinn and Thill 2004; Kyser et al. 2007; Sheley et al. 2007; Morris et al. 2009; Davies 2010), only two have measured imazapic performance in existing stands of native species (Davison and Smith 2007; Davies and Sheley 2011). In this study, we use field experiments to evaluate whether imazapic-induced reductions in cheatgrass competition increase native perennial abundance in remnant native plant communities of north-central Oregon. Our research is unique for its scale and duration. We tested imazapic in three different vegetation/soil types in large management scale plots and collected data over four posttreatment growing seasons to capture the persistence of herbicide effects and delayed responses of native vegetation. We hypothesized that 1 ) the use of imazapic would provide shortterm cheatgrass suppression and 2) cheatgrass suppression would allow for increases in native perennial species abundance.

\section{METHODS}

\section{Site Description}

The study was conducted at the Boardman Conservation Area, located in Morrow County, in north-central Oregon $\left(45^{\circ} 40^{\prime} 0^{\prime \prime} \mathrm{N}, 119^{\circ} 47^{\prime} 12^{\prime \prime} \mathrm{W}\right)$. The property is owned by Threemile Canyon Farms but managed by The Nature Conservancy under a lease agreement. Elevation ranges from 200 to $260 \mathrm{~m}$, and annual precipitation averages $22 \mathrm{~cm} \cdot \mathrm{yr}^{-1}$. Up to half of the precipitation falls in winter as snow, and less than $10 \%$ of the total precipitation occurs during the summer months. Monthly mean temperatures range from $5^{\circ} \mathrm{C}$ to $32^{\circ} \mathrm{C}$, with lows below freezing in the winter and highs in excess of $38^{\circ} \mathrm{C}$ in the summer (Western Regional Climate Center 2009).

\section{Experimental Design}

We used a completely randomized experimental design to investigate the impact of imazapic on nonnative and native vegetation. There were two treatment levels, each with three replicates: either sprayed with $70 \mathrm{~g}$ ai $\cdot \mathrm{ha}^{-1}$ of imazapic (Plateau; BASF Corporation, Research Triangle Park, NC) or unsprayed (control). A pilot study at the Boardman Conservation Area indicated this concentration effectively controlled cheatgrass without reducing native perennial plant species frequencies (N.T. Rudd, unpublished data).

We conducted the fully replicated experiment in three different native vegetation types: 1) bluebunch wheatgrass (Pseudoroegneria spicata [Pursh] A. Löve ssp. spicata)/needle and thread (Hesperostipa comata [Trin. \& Rupr.] Barkworth) dominated (BWNT), occurring on Warden silt loams (Xeric Haplocambids), 2) needle and thread/Sandberg bluegrass (Poa secunda J. Presl) dominated (NTSB), occurring on Quincy loamy fine sands (Xeric Torripsamments), and 3) big sagebrush (Artemisia tridentata Nutt.) dominated (BS), occurring on Sagehill fine sandy loams (Xeric Haplocalcids). The three sites are located 4-9 km apart.

Treatments were applied to 2.5-ha plots at BWNT and to 4ha plots at NTSB and BS. The presence of a road and existing fencing constrained the size of the plots at the BWNT site. Herbicide was aerial sprayed by helicopter on 12 October 2004 in the early to midafternoon using large-orifice nozzles calibrated to deliver $94 \mathrm{~L} \cdot \mathrm{ha}^{-1}$. Air temperature was $18-21^{\circ} \mathrm{C}$, and winds were negligible. No adjuvants were added to the herbicide mixture. Grazing exclosures protected sites from cattle grazing over the course of the study, although the BWNT site was temporarily grazed in 2004 for approximately $1 \mathrm{wk}$ when an electric fence failed.

We sampled a $100 \mathrm{~m}$ by $100 \mathrm{~m}$ area in the BWNT treatment plots and a $150 \mathrm{~m}$ by $150 \mathrm{~m}$ area in the NTSB and BS treatment plots. Sampling in each plot consisted of recording all species present in 100 one-meter-square nested frequency quadrat frames. Ten quadrats were placed along each of 10 transects located parallel to a permanently marked baseline transect. In the BWNT plots, the baseline and parallel transects were $100 \mathrm{~m}$ long, and parallel transects and quadrats were placed $10 \mathrm{~m}$ apart after a random starting point. In the NTSB and BS plots, the baseline and parallel transects were $150 \mathrm{~m}$ long, and parallel transects and quadrats were placed $15 \mathrm{~m}$ apart after a random starting point. Nested frequency quadrat frames consisted of four nested plot sizes: $0.001 \mathrm{~m}^{2}(3.16 \times 3.16 \mathrm{~cm})$, $0.01 \mathrm{~m}^{2}(10 \times 10 \mathrm{~cm}), 0.1 \mathrm{~m}^{2}(31.62 \times 31.62 \mathrm{~cm})$, and $1 \mathrm{~m}^{2}$ $(100 \times 100 \mathrm{~cm})$. Presence was scored for the smallest nested plot within which a species was rooted. Nested frequency sampling allows for selection of the most appropriate plot size when examining changes in frequency for many species. The nested plot size where frequencies are $30-70 \%$ in the first year of sampling area are considered ideal for detecting upward or downward changes in future years (Elzinga et al. 1998). Only 
plants alive during the sampling growing season were recorded. Data were collected between 16 April and 17 June every year for $5 \mathrm{yr}, 1 \mathrm{yr}$ before treatment application (2004) and $4 \mathrm{yr}$ posttreatment (2005-2008). A list of all species encountered at each site is provided in Table S1 (available online at http:// dx.doi.org/10.2111/REM-D-10-00163.s1).

\section{Data Analysis}

For each site, we used repeated measures analysis of variance to test for herbicide effects on each species, setting $\alpha=0.1$. We restricted the analysis to species at or greater than $15 \%$ frequency in any year in the best-fit quadrat size (i.e., the quadrat size with average frequency closest to $50 \%$ ) to include only the more common species most likely to exhibit a clear response to herbicide. We first considered whether time trends differed for imazapic and control by consulting the univariate, within-subjects $F$ test for the Year $\times$ Treatment interaction output by the REPEATED statement of PROC GLM in SAS 9.1 (Littel et al. 1998; von Ende 2001; SAS Institute 2004). Species with significant interactions were further examined with the CONTRAST transformation to determine the timing and duration of herbicide effects. This command generates individual analysis of variances (ANOVAs) that test for an herbicide effect on the change in frequency from pretreatment to each posttreatment year (von Ende 2001).

Univariate $F$ tests for within-subjects effects assume that the variance of the difference between any two levels of the withinsubjects are equal, a condition referred to as circularity and assessed with Mauchly's test for sphericity in SAS (von Ende 2001). This assumption is generally unrealistic because repeated measurements often become less correlated over time. To account for violations of sphericity, we used the Greenhouse-Geiser-adjusted $P$ values to determine the significance of the Year $\times$ Treatment interaction (Littel et al. 1998). Preto-posttreatment contrasts do not assume circularity, and so no correction was needed for this part of the analysis. The arcsinesquare-root transformation was used to reduce the likelihood of violating assumptions of sphericity and normality (Zar 1996). Mean square errors are provided with $P$ values as the relevant measure of variation associated with the repeated measures analysis. Annual mean (and standard error [SE]) percent frequency for all species analyzed for treatment effects are in Table S2 (available online at http://dx.doi.org/10.2111/REM-D10-00163.s2). Statistically significant treatment effects, expressed as the difference between pre-to-posttreatment change in herbicide and control plots, were generally greater than $15 \%$ frequency.

\section{RESULTS}

\section{Effects on Cheatgrass}

Imazapic reduced cheatgrass frequency to $0 \%\left(0.01-\mathrm{m}^{2}\right.$ quadrats) in the first spring after application at all sites, but the duration of suppression varied among sites (Table 1; Fig. 1). Herbicide effectiveness was most persistent at NTSB, where it remained statistically significant through the fourth posttreatment year despite an increase in cheatgrass at the site as observed in control plots. At BS and BWNT, imazapic reduced cheatgrass through the third year after spraying. The treatment effect, defined as the difference between spray and control in the amount of change from pre- to each posttreatment year, diminished most rapidly at BWNT, where cheatgrass in controls declined and remained less abundant after 2004. The difference between change in spray and control to 2008 was very similar to that observed in 2007 (21 vs. 22, respectively), but residual variance (mean standard error [MSE]) was much higher in 2008 (Tables 1 and S2).

\section{Effects on Nonnative Annual Forb Species}

We observed significant treatment effects on pre-to-posttreatment trends for several other annual nonnatives, but low pretreatment abundance complicated interpretation for some species. Redstem stork's bill (Erodium cicutarium [L.] L'Hér. ex Ait.) trends were similar to those of cheatgrass and imply a direct imazapic effect. Plants were eliminated the first year after spraying, and frequency remained lower in sprayed plots throughout the study at all sites. Treatment effects were smaller at the BS site due to lower pretreatment abundance in herbicide plots and little or no increase over time in control plots (Tables 1 and S2). Tall tumblemustard (Sisymbrium altissimum L.) frequencies trended lower in sprayed plots compared to unsprayed plots in 2005 at both the NTSB and BWNT sites, but the connection to treatment is questionable at BWNT due to low abundance in both herbicide and control plots (Tables 1 and S2). Russian thistle (Salsola kali L.) increased in sprayed plots at two sites. It was significantly greater in sprayed plots in the first two years after spraying at the BWNT site and in the second through the fourth years at the NTSB site (Tables 1 and S2).

\section{Effects on Native Annual Species}

Imazapic impacted all native annual species above the $15 \%$ frequency threshold, except for western tansymustard (Descurainia pinnata [Walt.] Britt.), but effects were highly variable among species and sites (Tables 1 and S2). Only small fescue (Vulpia microstachys [Nutt.] Monro), annual agoseris (Agoseris heterophylla [Nutt.] Greene), tall annual willowherb (Epilobium brachycarpum K. Presl), and mountain tarweed (Madia glomerata Hook.) were reduced for more than one posttreatment year. These species remained significantly less abundant in sprayed plots for $2 \mathrm{yr}$ at the BWNT site; tall annual willowherb remained absent in sprayed plots for $2 \mathrm{yr}$ at the BS site. Fiddleneck (Amsinckia sp.) was reduced in sprayed plots for $1 \mathrm{yr}$ at both BS and NTSB sites but increased in 2008. Tufted wirelettuce (Stephanomeria paniculata Nutt.) was significantly greater in sprayed plots in the third and fourth years following treatment at the NTSB site.

\section{Effects on Native Perennial Species}

We found little evidence to suggest that imazapic leads to a compensatory response in native perennials (Tables 1 and S2). The only native perennials exhibiting significant effects of imazapic on pre-to-posttreatment change were hoary tansyaster (Machaeranthera canescens [Pursh] Gray) and big sagebrush. Hoary tansyaster increased significantly in sprayed plots by the third and fourth years after treatment at the BS site but decreased in these $2 \mathrm{yr}$ at the NTSB site (Figs. 2A and 2B). The decline at NTSB is not attributable to herbicide because frequency decreased even more in the control. Big sagebrush decreased slightly with treatment in 2005 at the BS site but then 
Table 1. Repeated measure ANOVA summary for each site, 2004-2008. Mean square error (MSE, $d f=16$ ) and Greenhouse-Geiser adjusted $P$ values are given for tests of the Year $\times$ Treatment interaction. Where this is significant, MSE $(\mathrm{df}=4)$ and $P$ values are given for contrasts testing for an herbicide effect on change from pre- to each posttreatment year. Analysis on arcsine square-root transformed data. MSE multiplied by 1000 to avoid excessive decimal places. Significant tests are in bold text $(P<0.1)$.

\begin{tabular}{|c|c|c|c|c|c|c|c|c|c|c|}
\hline & \multicolumn{2}{|c|}{ Within-subjects analysis } & \multicolumn{8}{|c|}{ Herbicide effect on change from 2004 to } \\
\hline & \multirow[b]{2}{*}{ MSE } & \multirow{2}{*}{$\begin{array}{l}\text { Year } \times \text { Treat- } \\
\text { ment adjusted } P\end{array}$} & \multicolumn{2}{|c|}{2005} & \multicolumn{2}{|c|}{2006} & \multicolumn{2}{|c|}{2007} & \multicolumn{2}{|c|}{2008} \\
\hline & & & MSE & $P$ & MSE & $P$ & MSE & $P$ & MSE & $P$ \\
\hline \multicolumn{11}{|c|}{ Bluebunch wheatgrass/needle-and-thread site (BWNT) } \\
\hline \multicolumn{11}{|l|}{ Nonnative annuals } \\
\hline Cheatgrass & 8.771 & 0.0025 & 33.631 & 0.0077 & 20.827 & 0.0731 & 9.595 & 0.0232 & 37.337 & 0.2022 \\
\hline Prickly lettuce & 5.626 & 0.262 & - & - & - & - & - & - & - & - \\
\hline Redstem stork's bill & 5.658 & $<.0001$ & 13.863 & 0.0003 & 11.266 & 0.0079 & 21.842 & 0.0188 & 13.428 & 0.0074 \\
\hline Russian thistle & 9.77 & 0.0649 & 15.365 & 0.0352 & 5.812 & 0.0056 & 27.09 & 0.2549 & 2.835 & 0.5074 \\
\hline Tall tumblemustard & 9.748 & 0.0456 & 5.086 & 0.0080 & 30.191 & 0.1819 & 25.032 & 0.8462 & 17.955 & 0.3090 \\
\hline \multicolumn{11}{|l|}{ Native annuals } \\
\hline Annual agoseris & 5.692 & 0.0176 & 25.458 & 0.0630 & 10.556 & 0.0382 & 6.8 & 0.6882 & 20.905 & 0.8491 \\
\hline Mountain tarweed & 8.194 & 0.0019 & 19.446 & 0.0023 & 8.046 & 0.3816 & 12.658 & 0.0963 & 44.16 & 0.6004 \\
\hline Small fescue & 3.175 & 0.0005 & 6.849 & 0.0007 & 6.036 & 0.0158 & 2.829 & 0.8112 & 1.024 & 0.2581 \\
\hline \multicolumn{11}{|l|}{ Tall annual } \\
\hline willowherb & 4.88 & 0.0186 & 16.215 & 0.0572 & 8.048 & 0.9287 & 18.285 & 0.1057 & 3.58 & 0.7073 \\
\hline Woolly plantain & 4.036 & 0.0011 & 8.313 & 0.0020 & 4.333 & 0.1958 & 11.609 & 0.8883 & 6.331 & 0.0911 \\
\hline \multicolumn{11}{|l|}{ Native perennials } \\
\hline \multicolumn{11}{|l|}{ Bluebunch } \\
\hline wheatgrass & 3.35 & 0.0975 & 4.807 & 0.1206 & 5.656 & 0.55 & 9.451 & 0.7957 & 11.903 & 0.1806 \\
\hline Broom snakeweed & 4.439 & 0.245 & - & - & - & - & - & - & - & - \\
\hline Longleaf phlox & 4.936 & 0.3463 & - & - & - & - & - & - & - & - \\
\hline Needle and thread & 7.051 & 0.4886 & - & - & - & - & - & - & - & - \\
\hline Sandberg bluegrass & 3.946 & 0.5713 & - & - & - & - & - & - & - & - \\
\hline Squirreltail & 3.706 & 0.5338 & - & - & - & - & - & - & - & - \\
\hline \multicolumn{11}{|c|}{ Needle-and-thread/Sandberg bluegrass site (NTSB) } \\
\hline \multicolumn{11}{|l|}{ Nonnative annuals } \\
\hline Cheatgrass & 6.743 & 0.0033 & 11.531 & 0.0014 & 12.369 & 0.0023 & 5.121 & 0.0007 & 9.201 & 0.0217 \\
\hline Redstem stork's bill & 11.384 & 0.004 & 39.992 & 0.0057 & 3.554 & 0.0006 & 12.927 & 0.0063 & 6.338 & 0.0022 \\
\hline Russian thistle & 21.545 & 0.0063 & 35.123 & 0.1512 & 86.324 & 0.0349 & 39.129 & 0.0050 & 61.648 & 0.0999 \\
\hline Tall tumblemustard & 8.71 & 0.0035 & 32.195 & 0.0084 & 10.868 & 0.0469 & 31.842 & 0.1612 & 22.088 & 0.2478 \\
\hline \multicolumn{11}{|l|}{ Native annuals } \\
\hline Fiddleneck & 8.4 & 0.0022 & 43.436 & 0.0344 & 4.679 & 0.2200 & 7.69 & 0.0572 & 20.221 & 0.0236 \\
\hline Slender phlox & 9.979 & 0.0021 & 6.669 & 0.0008 & 13.177 & 0.5975 & 14.5 & 0.2359 & 42.368 & 0.0326 \\
\hline Small fescue & 11.494 & 0.009 & 23.771 & 0.0046 & 16.17 & 0.1205 & 14.082 & 0.3474 & 30.494 & 0.9424 \\
\hline Tufted wirelettuce & 3.021 & 0.0016 & 5.822 & 0.4912 & 5.605 & 0.0736 & 9.06 & 0.0093 & 6.44 & 0.0102 \\
\hline Woolly plantain & 13.524 & 0.0528 & 35.107 & 0.0347 & 3.856 & 0.0830 & 6.063 & 0.9191 & 13.903 & 0.9000 \\
\hline \multicolumn{11}{|l|}{ Native perennials } \\
\hline Columbia milkvetch & 6.663 & 0.4508 & - & - & - & - & - & - & - & - \\
\hline Common yarrow & 6.557 & 0.7875 & - & - & - & - & - & - & - & - \\
\hline \multicolumn{11}{|l|}{ Douglas' } \\
\hline dustymaiden & 6.643 & 0.0601 & 8.628 & 0.1163 & 34.767 & 0.2444 & 16.309 & 0.5467 & 11.205 & 0.2172 \\
\hline Hoary tansyaster & 4.81 & 0.0776 & 10.272 & 0.5267 & 21.316 & 0.6902 & 5.581 & 0.0259 & 4.347 & 0.0392 \\
\hline Lemon scurfpea & 7.349 & 0.7192 & - & - & - & - & - & - & - & - \\
\hline Needle and thread & 4.272 & 0.2686 & - & - & - & - & - & - & - & - \\
\hline Sandberg bluegrass & 2.642 & 0.1972 & - & - & - & - & - & - & - & - \\
\hline Yellow rabbitbrush & 4.215 & 0.3107 & - & - & - & - & - & - & - & - \\
\hline
\end{tabular}


Table 1. Continued.

\begin{tabular}{|c|c|c|c|c|c|c|c|c|c|c|}
\hline & \multicolumn{2}{|c|}{ Within-subjects analysis } & \multicolumn{8}{|c|}{ Herbicide effect on change from 2004 to } \\
\hline & \multirow[b]{2}{*}{ MSE } & \multirow{2}{*}{$\begin{array}{l}\text { Year } \times \text { Treat- } \\
\text { ment adjusted } P\end{array}$} & \multicolumn{2}{|c|}{2005} & \multicolumn{2}{|c|}{2006} & \multicolumn{2}{|c|}{2007} & \multicolumn{2}{|c|}{2008} \\
\hline & & & MSE & $P$ & MSE & $P$ & MSE & $P$ & MSE & $P$ \\
\hline \multicolumn{11}{|l|}{ Big sagebrush site (BS) } \\
\hline \multicolumn{11}{|l|}{ Nonnative annuals } \\
\hline Cheatgrass & 5.46 & 0.0013 & 9.536 & 0.0007 & 18.553 & 0.0287 & 30.484 & 0.0760 & 12.782 & 0.7991 \\
\hline Prickly lettuce & 4.308 & 0.008 & 1.576 & $<0.0001$ & 2.823 & 0.0333 & 10.689 & 0.0343 & 7.075 & 0.8134 \\
\hline $\begin{array}{l}\text { Redstem stork's bill } \\
\text { Native annuals }\end{array}$ & 9.635 & 0.008 & 27.955 & 0.0101 & 13.282 & 0.0527 & 20.396 & 0.0378 & 29.128 & 0.0601 \\
\hline Annual agoseris & 14.514 & 0.2345 & - & - & - & - & - & - & - & - \\
\hline Fiddleneck & 8.065 & 0.0009 & 12.905 & 0.0031 & 5.701 & 0.9748 & 11.417 & 0.0759 & 21.846 & 0.0862 \\
\hline Mountain tarweed & 45.848 & 0.1777 & - & - & - & - & - & - & - & - \\
\hline $\begin{array}{l}\text { Small fescue } \\
\text { Tall annual }\end{array}$ & 19.444 & 0.0024 & 84.195 & 0.0191 & 73.053 & 0.6733 & 75.524 & 0.3095 & 79.765 & 0.2006 \\
\hline willowherb & 8.62 & 0.0067 & 24.471 & 0.0074 & 7.93 & 0.0639 & 39.56 & 0.064 & 13.523 & 0.3249 \\
\hline $\begin{array}{l}\text { Western } \\
\text { tansymustard }\end{array}$ & 7.22 & 0.1709 & 一 & - & - & - & - & - & - & - \\
\hline \multicolumn{11}{|l|}{ Native perennials } \\
\hline Big sagebrush & 10.021 & 0.0108 & 10.574 & 0.0699 & 5.616 & 0.3837 & 34.373 & 0.1248 & 19.163 & 0.0370 \\
\hline $\begin{array}{l}\text { Broom snakeweed } \\
\text { Hairy false }\end{array}$ & 3.183 & 0.2338 & - & - & 一 & - & - & - & - & - \\
\hline goldenaster & 14.433 & 0.2385 & - & - & - & - & - & - & - & 一 \\
\hline Hoary tansyaster & 10.159 & 0.0056 & 7.952 & 0.1162 & 10.191 & 0.8841 & 49.64 & 0.0878 & 21.001 & 0.0157 \\
\hline $\begin{array}{l}\text { Sandberg bluegrass } \\
\text { Turpentine }\end{array}$ & 4.131 & 0.5764 & - & - & - & - & - & - & - & - \\
\hline wavewing & 2.528 & 0.1545 & - & - & - & - & - & - & - & - \\
\hline Yellow rabbitbrush & 13.207 & 0.0972 & 36.265 & 0.5383 & 14.859 & 0.5741 & 30.199 & 0.1543 & 37.906 & 0.4389 \\
\hline
\end{tabular}

increased significantly by 2008 (Fig. 2C). The increase was a result of seedling establishment initially observed in 2007. Significant Year $\times$ Treatment interactions suggest differences in trends for herbicide and control plots for three other species (bluebunch wheatgrass at BWNT, Douglas' dustymaiden at NTSB, yellow rabbitbrush at BS), typically due to a larger decline in control than sprayed plots. However, tests for imazapic effects on pre-to-posttreatment contrasts were not significant for these species (Table 1). In addition, none of the common native perennial grasses or other native perennial vegetation changed in response to imazapic at any site over the course of the study.

\section{DISCUSSION}

Our results suggest that imazapic is an effective tool for reducing cheatgrass and other nonnative annuals without long-term reductions in the abundance of remnant native plant species inhabiting three common vegetation types at the Boardman Conservation Area. Although imazapic initially suppressed some native annuals, all recovered by the third growing season after application. Our results also demonstrate that the duration of cheatgrass suppression is somewhat site specific, varying from three to four growing seasons. Other studies report cheatgrass suppression for one to two growing seasons, but these were typically shorter in duration or monitored less frequently. Davison and Smith (2007) report $2 \mathrm{yr}$ of reduction with treatment, the length of their study in a Wyoming big sagebrush community. Morris et al. (2009) observed cheatgrass reduction for only one growing season in a Wyoming big sagebrush community, but monitored only the first and third years after treatment. They attribute a 3-yr reduction in a salt desert shrub community at the highest application rate to below-normal autumn precipitation the second posttreatment year. Variations in imazapic effectiveness may result from differences in the amount of surface litter (Monaco et al. 2005; Kyser et al. 2007; Sheley et al. 2007) or other factors affecting its soil residual activity. Herbicide persistence in the imazapic family of herbicides is often greater in soils with higher clay contents (Barnes et al. 1989; Goetz et al. 1990; Grey et al. 2008), although in this study persistence was greatest in the site with the sandiest soils (i.e., the NTSB site).

Despite reductions in cheatgrass and other nonnative annuals, only two native perennial species, hoary tansyaster and big sagebrush, increased in abundance. Similarly, Davison and Smith (2007) found only one native perennial, Wyoming big sagebrush, to increase after cheatgrass suppression. In contrast, Davies and Sheley (2011) reported increased perennial grass and forb cover with fall-applied imazapic 1-2 yr after treatment; the response of large bunchgrasses was especially 


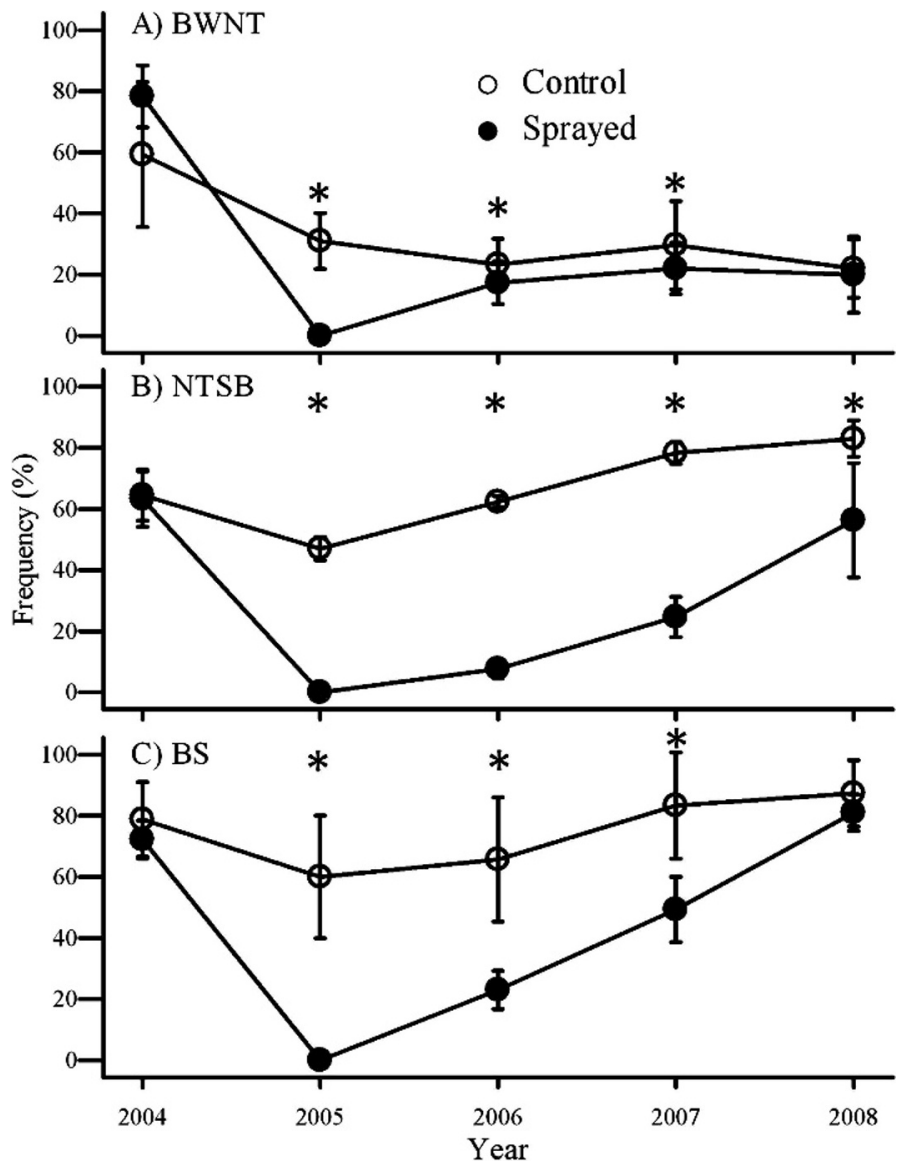

Figure 1. Time trends by treatment for cheatgrass in $0.01-\mathrm{m}^{2}$ quadrats (mean $\pm \mathrm{SE} ; \mathrm{N}=3$ ). Significant effects of imazapic on change from 2004 to each posttreatment year are denoted by an asterisk $(P<0.1)$. $\mathbf{A}$, BWNT = bluebunch wheatgrass/needle and thread site; $\mathbf{B}$, NTSB $=$ needle and thread/Sandberg bluegrass site; C, BS = big sagebrush site.

pronounced when imazapic was preceded by fall or spring burning. Potential factors limiting the response to reduced cheatgrass competition in our study include unfavorable climatic conditions for seedling establishment, limited seed sources, or imazapic suppression of established perennials or seedling establishment.

In semiarid ecosystems, the establishment of native perennials can be episodic (Humphrey and Schupp 1999; Chambers 2000; Bakker et al. 2003) and may require specific climatic conditions that did not occur during our study, for example, several years of above average precipitation. Total spring growing season precipitation (March-May) was at or above average the first and second year after imazapic application $(5.2 \mathrm{~cm}$ and $6.5 \mathrm{~cm}$, respectively, compared to the $5 \mathrm{~cm}$ average) but was below average in the third and fourth year $(4.1 \mathrm{~cm}$ and $2.6 \mathrm{~cm}$, respectively). Multiple imazapic applications over time may allow cheatgrass suppression to coincide with favorable conditions for seedling establishment.

Even with an ideal climate, however, regeneration may still be limited by an inadequate quantity of viable seed. Although remnant native species persist at our study sites, seed rain and soil seed banks may be insufficient to take advantage of temporary reductions in cheatgrass competition. Seed banks of native perennial species in shrub-steppe

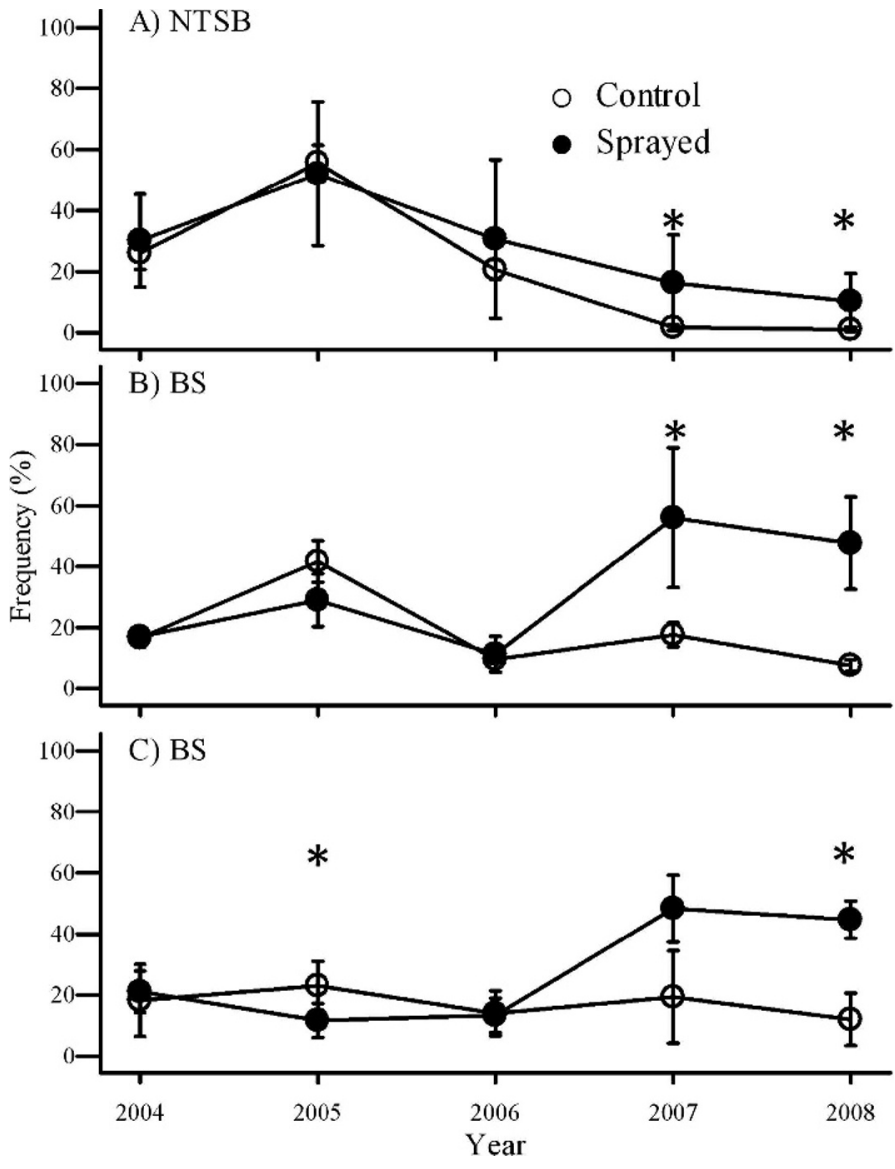

Figure 2. Time trends by treatment for hoary tansyaster and big sagebrush in $1-\mathrm{m}^{2}$ quadrats (mean $\pm \mathrm{SE} ; \mathrm{N}=3$ ). Significant effects of imazapic on change from 2004 to each posttreatment year are denoted by an asterisk $(P<0.1)$. A, hoary tansyaster at NTSB $=$ needle and thread/Sandberg bluegrass site; $\mathbf{B}$, hoary tansyaster at $B S=$ big sagebrush site; $\mathbf{C}$, big sagebrush at $B S=$ big sagebrush site.

communities tend to be sparse (Hassan and West 1986; Young et al. 1987; Humphrey and Schupp 2001). Therefore a more effective strategy may be to combine seeding with imazapic application.

However, we advocate further research to evaluate effects of single or repeated imazapic applications on existing native perennials and their establishment and seed production before large-scale use in restoration of native plant communities. Imazapic has been shown to suppress some perennials (Beran et al. 1999; Shinn and Thill 2004; Kyser et al. 2007; Morris et al. 2009), and the minimal native response to reduced cheatgrass competition in our study may be at least partly attributable to this effect. While we found no evidence to suggest that imazapic suppressed established native perennials, other studies have documented negative impacts on native perennial grasses. Imazapic applied in the spring with methylated seed oil reduced both biomass and height of established perennial grasses (Shinn and Thill 2004) and injured smooth brome for up to 90 days after treatment (Shinn and Till 2002). Imazapic was also associated with reduced perennial grass cover in one of two sites as rates increased from $70 \mathrm{~g}$ ai $\cdot \mathrm{ha}^{-1}$ to $140 \mathrm{~g}$ ai $\cdot \mathrm{ha}^{-1}$ (Monaco et al. 2005), although Sheley et al. (2007) found no consistent response in perennial grass or forb cover to imazapic rate. Adjuvants may 
be partly responsible for imazapic effects on native grasses in these other studies. Also, frequency is not as sensitive a measure of abundance as biomass or cover, so it is possible that we missed small reductions in density or cover of native perennials.

Imazapic has also been shown to suppress seedling establishment of some perennials, but at rates of $105 \mathrm{~g} \mathrm{ai} \cdot \mathrm{ha}^{-1}$ and above (Morris et al. 2009), which is higher than the $70 \mathrm{~g}$ ai $\cdot \mathrm{ha}^{-1}$ used in this study. There is some evidence of imazapic impacts on perennial seed production. Baker et al. (1999) report that single and repeated application substantially decreases seed head production in bahiagrass (Paspalum notatum), a tropical perennial turf grass. Herbicides can reduce reproductive output of nontarget native plants without effecting short-term abundance, thereby leading to long-term population declines (Crone et al. 2009). In addition, an unintended consequence of imazapic treatment was an increase in the nonnative annual Russian thistle. Thickets of dead Russian thistle persist for several years, altering vegetative structure and potentially inhibiting establishment of native species.

In conclusion, our results demonstrate that a single application of imazapic can reduce cheatgrass for 3-4 years in remnant native plant communities of north central Oregon. However, other strategies are clearly needed to prevent reinvasion and foster the increase of native perennials. We advocate further research to determine the long-term effectiveness of other management approaches for cheatgrass-infested native communities, including multiple herbicide applications, prescribed burning prior to herbicide, and seeding of native species.

\section{IMPLICATIONS}

The herbicide imazapic has emerged as a promising tool for suppressing cheatgrass and other nonnative annual grasses. In remnant native plant communities, management strategies that provide temporary reductions in cheatgrass could potentially allow native species to increase in abundance and resist further cheatgrass invasion without requiring reseeding. In this study imazapic did successfully suppress cheatgrass and other nonnative annuals for 3-4 years, depending on the site, with minimal negative impacts to native species. However, only two native perennial plant species, hoary tansyaster and big sagebrush, increased in abundance over the course of the study. These results suggest that simply reducing cheatgrass may not be an effective tool for increasing most native perennial plants, even when remnant native perennials are present. Other strategies such as multiple imazapic applications, prescribed burning prior to herbicide, or combining seeding with imazapic application may be more effective at preventing reinvasion and increasing native species. However, further research is needed to evaluate the effects of imazapic on seed production and seedling establishment for a range of native species.

\section{ACKNOWLEDGMENTS}

We thank Leslie Nelson for coordinating the study, and Lori Tella, Ken Hall, Michelle Mattocks, Rachel Neugarten, and Nathan Emery for assisting with data collection.

\section{LITERATURE CITED}

AguirRe, L., and D. A. Johnson. 1991. Influence of temperature and cheatgrass competition on seedling development of two bunchgrasses. Journal of Range Management 44:347-354.

Baker, R. D., L. B. McCarty, D. L. Colvin, J. M. Higgins, J. S. Weinbrecht, and J. E. Moreno. 1999. Bahiagrass (Paspalum notatum) seedhead suppression following consecutive yearly applications of plant growth retardants. Weed Technology 13:378-384.

BAKKER, J. D., AND S. D. WILSON. 2004. Using ecological restoration to constrain biological invasion. Journal of Applied Ecology 41:1058-1064.

Bakker, J. D., S. D. Wilson, J. Christian, X. LI, L. Ambrose, and J. Waddington. 2003. Contingency of prairie restoration success on year, site and competition from introduced grasses. Ecological Applications 13:137-153.

Barnes, C. J., A. J. Goetz, And T. L. Lavy. 1989. Effects of imazaquin residues on cotton (Gossypium hirsutum). Weed Science 37:820-824.

Beran, D. D., R. A. Masters, and R. E. Gaussoin. 1999. Grassland legume establishment with imazethapyr and imazapic. Agronomy Journal 91:592-596.

BIondINI, M. 2007. Plant diversity, production, stability, and susceptibility to invasion in restored northern tall grass prairie (United States). Restoration Ecology 15:77-87.

Blumenthal, D. M., N. R. Jordan, and E. L. Svenson. 2003. Weed control as a rationale for restoration: the example of the tallgrass prairie. Conservation Ecology 7:6. Available at: http://www.consecol.org/vol7/iss1/art6. Accessed 5 May 2009.

Chambers, J. C. 2000. Seed movements and seedling fates in disturbed sagebrush steppe ecosystems: implications for restoration. Ecological Applications 10:1400-1413.

Cox, R. D., And V. J. Anderson. 2004. Increasing native diversity of cheatgrassdominated rangeland through assisted succession. Journal of Range Management 57:203-210.

Crone, E. E., M. Marler, and D. E. Pearson. 2009. Non-target effects of broadleaf herbicide on a native perennial forb: a demographic framework for assessing and minimizing impacts. Journal of Applied Ecology 46:673-682.

Davies, K. W. 2010. Revegetation of medusahead-invaded sagebrush steppe. Rangeland Ecology \& Management 63:564-571.

Davies, K. W., And R. L. Sheley. 2011. Promoting native vegetation and diversity in exotic annual grass infestations. Restoration Ecology 19:159-165.

Davison, J. C., AND E. G. Smitr. 2007. Imazapic provides 2-year control of weedy annuals in a seeded Great Basin fuelbreak. Native Plants Journal 8:91-95.

Elzinga, C. L., D. W. Salzer, and J. W. Willoughby. 1998. Measuring and monitoring plant populations. BLM Technical Reference 1730-1. Denver, CO, USA: Bureau of Land Management. $477 \mathrm{p}$.

Goetz, A. J., T. L. Lavy, and E. E. Gbur, JR. 1990. Degradation and field persistence of imazethapyr. Weed Science 38:421-428.

Grey, T. L., A. MacRae, and A. S. Culpepper. 2008. Transplanted onion response to previously applied residual herbicides. Weed Technology 22:477-480.

HarRIS, G. A. 1967. Some competitive relationships between Agropyron spicatum and Bromus tectorum. Ecological Monographs 37:89-111.

Hassan, M. A., And N. E. West. 1986. Dynamics of soil seed pools in burned and unburned sagebrush semi-deserts. Ecology 67:269-272.

Hull, A. C., And W. T. Hansen, JR. 1974. Delayed germination of cheatgrass seed. Journal of Range Management 27:366-368.

Humphrey, L. D., AND E. W. Schupp. 1999. Temporal patterns of seedling emergence and early survival of Great Basin perennial plant species. Great Basin Naturalist 59:35-49.

Humphrey, L. D., and E. W. Schupp. 2001. Seed banks of Bromus tectorumdominated communities in the Great Basin. Western North American Naturalist 61:85-92.

KNAPP, P. A. 1996. Cheatgrass (Bromus tectorum $L$ ) dominance in the Great Basin Desert: history, persistence, and influences to human activities. Global Environmental Change 6:37-52.

KNICK, S. T. 1999. Requiem for a sagebrush ecosystem? Northwest Science 73:53-57.

Kyser, G. B., J. M. DiTomaso, M. P. Doran, S. B. Orloff, R. G. Wilson, D. L. Lancaster, D. F. Lile, and M. L. Porath. 2007. Control of medusahead (Taeniatherum 
caput-medusae) and other annual grasses with imazapic. Weed Technology 21:66-75.

LitTel, R. C., P. R. Henry, and C. B. Ammerman. 1998. Statistical analysis of repeated measures data using SAS procedures. Journal of Animal Science 76: $1216-1231$.

MAcK, R. N. 1981. Invasion of Bromus tectorum L. into western North America: an ecological chronicle. Agro-Ecosystems 7:145-165.

Melgoza, G., R. S. Nowak, and R. J. TAusch. 1990. Soil water exploitation after fire: competition between Bromus tectorum (cheatgrass) and two native species. Oecologia 83:7-13.

Menakis, J. P., D. Osborne, And M. Miller. 2003. Mapping the cheatgrass-caused departure from historical natural fire regimes in the Great Basin, USA. In: P. N. Omi and L. A. Joyce [EDS.]. Fire, fuel treatments, and ecological restoration: conference proceedings; 16-18 April 2002; Fort Collins, C0, USA Washington, DC, USA: US Department of Agriculture, Forest Service, RMRSP-29. p. 281-287.

Monaco, T. A., T. M. Osmond, and S. A. Dewey. 2005. Medusahead control with falland spring-applied herbicides on northern Utah foothills. Weed Technology 19:653-658.

Monsen, S. B., R. Stevens, and N. L. Shaw. 2004. Restoring western ranges and wildlands. General Technical Report RMRS-GTR-136-vol-1-3. Fort Collins, CO, USA: US Department of Agriculture, Forest Service, Rocky Mountain Research Station.

Morris, C., T. A. Monaco, and C. W. RigBy. 2009. Variable impacts of imazapic rate on downy brome (Bromus tectorum) and seeded species in two rangeland communities. Invasive Plant Science and Management 2: 110-119.

Mosely, J. C., S. C. Bunting, and M. E. Manoukian. 1999. Cheatgrass. In: R. L. Sheley and J. K. Petroff [EDS.]. Biology and management of noxious rangeland weeds. Corvallis, OR, USA: Oregon State University Press. p. 175-188.

Norton, J. B., T. A. Monaco, J. M. Norton, D. A. Johnson, T. A. Jones. 2004. Cheatgrass invasion alters soil morphology and organic matter dynamics in big sagebrush-steppe rangelands. In: A. L. Hild, N. L. Shaw, S. E. Meyer, D. T. Booth, and E. D. McArthur [Comps.]. Proceedings: Seed and soil dynamics in shrubland ecosystems; 12-16 August 2002; Laramie, WY, USA. Fort Collins, CO, USA: US Department of Agriculture, Forest Service, RMRS-P31. p. $57-63$.

Pellant, M. 1990. The cheatgrass-wildfire cycle-are there any solutions? In: E. D. McArthur, E. M. Romney, S. D. Smith, and P. T. Tueller [Comps.]. Proceedings: Symposium on cheatgrass invasion, shrub die-off, and other aspects of shrub biology and management; 5-7 April 1989; Las Vegas, NV, USA. Ogden, UT, USA: US Department of Agriculture, Forest Service, General Technical Report Int-276. p. 11-18.
Pellant, M. 1996. Cheatgrass: the invader that won the West. Boise, ID, USA: Bureau of Land Management, Interior Columbia Basin Ecosystem Management Project. $22 p$.

Peters, E. F., and S. C. Bunting. 1994. Fire conditions pre- and postoccurrence of annual grasses on the Snake River Plain. In: S. B. Monsen, and S. G. Kitchen [comps.]. Proceedings: Ecology and management of annual rangelands; 18-22 May 1992; Boise, ID, USA. Ogden, UT, USA: US Department of Agriculture, Forest Service, General Technical Report INT-GTR-313. p. $31-36$

SAS InSTITUTE. 2004. SAS/STAT 9.1 user's guide. Cary, NC, USA: SAS Institute. $200 \mathrm{p}$.

Sheley, R. L., M. F. Carpinelli, and K. J. Reever Morghan. 2007. Effects of imazapic on target and nontarget vegetation during revegetation. Weed Technology 21:1071-1081.

Shinn, S. L., AND D. C. Thill. 2002. The response of yellow starthistle (Centaurea solstitialis), annual grasses, and smooth brome (Bromus inermis) to imazapic and picloram. Weed Technology 16:366-370.

SHInN, S. L., and D. C. THILL. 2004. Tolerance of several perennial grasses to imazapic. Weed Technology 18:60-65.

Stewart, G., and A. C. Hull. 1949. Cheatgrass (Bromus tectorum L.)-an ecologic intruder in southern Idaho. Ecology 30:58-74.

USDA, NRCS. 2011. The PLANTS database. Available at: http://plants.usda.gov. Accessed 6 June 2011.

Von Ende C. N. 2001. Repeated measures analysis: growth and other timedependent measures. In: S. M. Scheiner, and J. Gurevitch [EDS.]. Design and analysis of ecological experiments. New York, NY, USA: Oxford University Press. p. 134-157.

Western Regional Climate Center. 2009. Boardman, Oregon 1971-2000 monthly climate summary. Available at: http://www.wrcc.dri.edu/cgi-bin/cliMAIN. pl?or0858. Accessed 1 June 2009.

Whisenant, S. G. 1990. Changing fire frequencies on Idaho's Snake River Plains: ecological and management implications. In: E. D. McArthur, E. M. Romney, S. D. Smith, and P. T. Tueller [comps.]. Proceedings: Symposium on cheatgrass invasion, shrub die-off, and other aspects of shrub biology and management; 5-7 April 1989; Las Vegas, NV, USA. Ogden, UT, USA: US Department of Agriculture, Forest Service, General Technical Report Int-276. p. 4-10.

Young, J. A., and R. A. Evans. 1978. Population dynamics after wildfires in sagebrush grasslands. Journal of Range Management 31:283-289.

Young, J. A., R. A. Evans, R. E. Eckert, JR., and B. L. Kay. 1987. Cheatgrass. Rangelands 9:266-270.

ZaR, J. H. 1996. Biostatistical analysis. 3rd ed. Upper Saddle River, NJ, USA: Prentice Hall. 662 p. 